\title{
Analyzing Entrepreneurship Skill Levels of the 3rd Grade Primary School Students in Life Sciences Course Based on Different Variables
}

\author{
Hüseyin Polat ${ }^{1}$ \\ ${ }^{1}$ Department of Basic Education, Education Faculty, Adiyaman University, Adıyaman, Turkey \\ Correspondence: Hüseyin Polat, Department of Basic Education, Education Faculty, Adiyaman University, \\ Adiyaman, Turkey. E-mail: hpolat@adiyaman.edu.tr
}

\author{
Received: December 15, 2017 \\ Accepted: January 22, $2018 \quad$ Online Published: March 28, 2018 \\ doi:10.5539/ies.v11n4p63 \\ URL: https://doi.org/10.5539/ies.v11n4p63
}

\begin{abstract}
The purpose of this study is to investigate Life Sciences course entrepreneurship skills of the $3^{\text {rd }}$ grade primary school students as evaluated by their parents. The study was conducted with the screening model. The participants of the study were the parents ( 47 mothers and 23 fathers) of the students ( 32 girls, 38 boys) who study in the center of the province of Adiyaman, Turkey, in the academic year of 2017-2018. In order to collect the data, "entrepreneurship skill condition" survey form, which evaluates the entrepreneurial gains from the $1^{\text {st }}$ and $2^{\text {nd }}$ grade Life Sciences course, was used. According to the findings, the entrepreneurship skill level of the students was found 98.81 out of 130, which is "good". The entrepreneurship skill level of the students showed a significant difference depending on the parent variable, where mothers evaluated their children more favorably compared to fathers. The entrepreneurship skill level of the students did not show a significant difference depending on their gender. Depending on their success in the school and the Life Sciences course, however, there was a significant difference $(\mathrm{p}<0.05)$ in their entrepreneurship skill level. A positive correlation was detected between the entrepreneurship skill level and the success in the school and the Life Sciences course. The entrepreneurship skill level of the students also varied significantly $(p<0.05)$ depending on their self-confidence level. High self-confidence and the entrepreneurship skill level were found to be positively correlated.
\end{abstract}

Keywords: entrepreneurship skills, life sciences course, entrepreneurship

\section{Introduction}

Since the primary school children see facts and events as a whole, it is not appropriate to divide the courses into scientific fields such as history, geography, physics, chemistry, biology and civic studies (Sönmez, 2010, p. 5). Therefore, the curriculum of the Life Sciences course, which is formed with an interdisciplinary approach and the principle of "consolidation in education", includes topics such as family, home, school and immediate surroundings in accordance with the children's experience (Kabapınar, 2009, p. 1). According to Akınoğlu (2008, p. 2), the purpose of the Life Sciences is to prepare the children for life so that they can choose the best option when they encounter any problems.

Life Sciences have been a pivot course in the Ottoman education program since 1869 as well as the education program of the Republic of Turkey ever since its foundation. It is observed that the purpose and the content of the course have been continuously changing in order to fulfill the immediate needs of the era (Şahin, 2009; Ünişen, 2013). The cognitive basis, which is required for individuals to build norms to interact with their environment, to become aware of their own potential, to develop it in their social structure and to get to work, is introduced to the children with the Life Sciences course in the primary school (Polat \& Ünişen, 2016). In this aspect, the Life Sciences course is the focal point of education since it guides children to efficiently, positively and successfully adjust to the society.

As one of the basic qualifications in the Qualifications Framework of Turkey, which is taken as a reference when constituting new programs, "Taking Initiative and the Sense of Entrepreneurship" is included in the curriculum of the Life Sciences course just like other qualifications, since Life Sciences is a pivot course. This key qualification includes "the individuals' ability to turn their thoughts into actions; carrying out and planning projects as well as being creative and open to innovation and taking risks in order to achieve goals, and taking ethical values into consideration and showing good management skills while doing so". Also, "entrepreneurship" is listed as one of the 24 basic life skills in the program (M.E.B., 2017). 
The 2017 Life Sciences curriculum for the $1^{\text {st }}, 2^{\text {nd }}$ and $3^{\text {rd }}$ grades was only implemented for the $1^{\text {st }}$ grade students in the academic year of 2017-2018. Therefore, in this study, the 2010 Life Sciences curriculum entrepreneurial gains from the $1^{\text {st }}, 2^{\text {nd }}$ and $3^{\text {rd }}$ grades were taken into consideration.

Table 1. Entrepreneurship skill gains of the 1st-3rd grade primary school students

\begin{tabular}{|c|c|c|c|}
\hline Grade & My Enthusiasm in School & My Precious Home & $\begin{array}{l}\text { Yesterday, Today, } \\
\text { Tomorrow }\end{array}$ \\
\hline 1 & $\begin{array}{l}\text { A.1.6. Accepts that she/he or her/his friends can make } \\
\text { mistakes while playing games. }\end{array}$ & & \\
\hline \multirow[t]{6}{*}{2} & $\begin{array}{l}\text { A.2.9. Guides, encourages and if necessary, helps } \\
\text { her/his friends with club and group work. }\end{array}$ & & \\
\hline & $\begin{array}{l}\text { A.3.13. Accepts that both winning and losing are } \\
\text { expected results of playing. }\end{array}$ & & \\
\hline & A.3.29. Is sensitive to the common needs of the group & & \\
\hline & that are unnoticed during club and group work. & & \\
\hline & $\begin{array}{l}\text { A.3.30. Helps her/his friends reach a consensus during } \\
\text { club and group work activities or decisions. }\end{array}$ & & \\
\hline & & $\begin{array}{l}\text { B.1.17. Accepts that she/he or her/his family } \\
\text { members can make mistakes and that it is only } \\
\text { natural. }\end{array}$ & \\
\hline \multirow[t]{5}{*}{1} & & B.1.24. Recognizes money as a tool of exchange & \\
\hline & & B.1.25. Recognizes that money is a limited source by & \\
\hline & & getting involved in the preparation phase of family & \\
\hline & & budget. & \\
\hline & & $\begin{array}{l}\text { B.2.18. Creates new ideas about the duties she/he } \\
\text { can carry out at home by observing the solidarity in }\end{array}$ & \\
\hline \multirow[t]{2}{*}{2} & & her/his family & \\
\hline & & $\begin{array}{l}\text { B.2.19. Is willing to take part in duties a family } \\
\text { requires and is happy to do her/his part }\end{array}$ & \\
\hline 3 & & B.3.33. By taking the risk of losing or failing, she/he & \\
\hline
\end{tabular}

As it can be seen on Table 1, the entrepreneurship skill gains, being one of the 14 skills in the 2010 Life Sciences curriculum, are included in the theme 'my enthusiasm in school' with 5 items and in the theme 'my precious home' with 6 items according to the principles of "being sensitive to the common needs of the group that are unnoticed, taking risks, being open to new ideas, information and skills, accepting potential failures and criticism, showing courage to try new things and enjoying them by taking the risk of losing".

Nowadays, entrepreneurship can either be a skill included in a course or a course on its own in formal education. It is in high demand among individuals with varying age and educational background. The entrepreneurship training, which provides the individuals with necessary skills and knowledge in order to build economic values and create their own job opportunities in liberal economies especially since the 1970s (Duval-Couetil, 2013), is offered in thousands of institutions only in the US (Kuratko, 2005), and is also one of the basic qualifications in the European education.

In the contemporary world, entrepreneurship is planned to be developed as a key skill, which is included in every level of education from primary school to graduate school. Even though the qualifications may vary, each level of the entrepreneurship training carries the same purpose. There are two basic approaches that are used prevalently; one of them defines entrepreneurship as recognizing and making use of opportunities, and the other one defines it as a set of competences. When the purpose is to make people adopt entrepreneurship as a discipline of its own without embedding it in another program, it is seen that the programs are prepared in accordance with Kolb's Learning Cycle including both theory and practice. This cycle consists of the following phases: a) concrete experience, b) reflective observation, c) abstract conceptualization, d) active experimentation (van der Sijde, Ridder, Blaauw, \& Deinsberg, 2008, p. 1).

Turkish entrepreneurship training literature consists of mostly theoretical studies; Güven (2010) conducted a study on the appropriateness of the life science program according to developing entrepreneurship skills; Eraslan (2011) 
also examined the life science program and developed suggestions about its application to develop entrepreneurship skills; Pan and Akay (2015) investigated entrepreneurship levels of the students at the faculty of educational sciences; Ay and Acar (2016) examined the views of the teachers regarding the acquisition of entrepreneurship skills; Çermik and Şahin (2015) tried to assess the social entrepreneurship traits of the prospective social sciences teachers; Çelik, İnce, and Bozyiğit (2014) studied familial factors related to entrepreneurial intentions of university students and Bozkurt and Erdurur (2013) examined the relation between entrepreneurial traits and the tendency towards entrepreneurship. As seen, the literature seems to focus on the program and lacks studies for early ages.

The purpose of this study is to investigate the Life Sciences course entrepreneurship skill level of the $3^{\text {rd }}$ grade students, who have successfully passed the $1^{\text {st }}$ and $2^{\text {nd }}$ grade Life Sciences courses, according to the observations of their parents.

\section{Methodology}

\subsection{The Research Methodology}

This study, which was carried out to determine the entrepreneurship skill gains of the $3^{\text {rd }}$ grade students, who successfully completed the Life Sciences course in the $1^{\text {st }}$ and $2^{\text {nd }}$ grades, was conducted with the screening model. These studies focus on; collecting evidence and evaluating it in order to find cases, observe correlations and make judgments regarding past events (Karasar, 1998, p. 78), collecting data in order to determine certain traits of a group (Büyüköztürk et al., 2008, p. 15), introducing and explaining the variables regarding the interest areas, detecting the relationship between these variables and exploring the distribution of these variables as well as relevant statistics (Arseven, 2000, p. 24).

\subsection{Population and Sample}

The population of this study consists of the parents of $3^{\text {rd }}$ grade students who study at the primary school "a" which is located in central Adiyaman, and the primary school "b" which is located in a disadvantaged neighborhood of central Adiyaman, in the academic year 2017-2018. As the parents were regarded to observe their children better than any other, 70 parents were included in the sample of the study on voluntary basis.

Table 2. Frequency and percentage distribution of the study group

\begin{tabular}{llcc}
\hline & & $\mathrm{f}$ & $\%$ \\
\hline \multirow{4}{*}{ School Type } & Central & 30 & 42.9 \\
& Disadvantaged Neighborhood & 40 & 57.1 \\
& Total & 70 & 100.0 \\
& Mother & 47 & 67.1 \\
& Father & 23 & 32.9 \\
& Total & 70 & 100.0 \\
& Female & 32 & 45.7 \\
& Male & 38 & 54.3 \\
& Total & 70 & 100.0 \\
\hline
\end{tabular}

As it can be seen on Table 2, $42.9 \%$ of the children/students in our study group attend primary school in a central location, whereas $57.1 \%$ of them attend primary school in a disadvantaged neighborhood. $67.1 \%$ of the 70 parents in this study were mothers, whereas $32.9 \%$ of them were fathers. $45.7 \%$ of the children/students were female, whereas $54.3 \%$ of them were male.

\subsection{Data Collection Tool}

In this study, the entrepreneurship skill gains of the $3^{\text {rd }}$ grade students, who passed the Life Sciences course successfully in the $1^{\text {st }}$ and $2^{\text {nd }}$ grades, were determined by consulting their parents.

Even though the curriculum of the Life Sciences course was changed in 2017, in the academic year of 2017-2018, $3^{\text {rd }}$ grade students attended the Life Sciences courses with the curriculum of 2010. A draft for the survey form, which includes 26 items created through transforming the gains to performance indicators. Some gains were transformed into more than 1 indicator. The 5 gains were (A.1.6, A.2.9, A.3.13, A.3.29, A.3.30) from the theme 'my enthusiasm in school (from the theme of 'my precious home' A.1.6, A.2.9, A.3.13, A.3.29, A.3.30) and the 6 gains (B.1.17, B.1.24, B.1.25, B.2.18, B.2.19, B.3.33), regarding entrepreneurship. Based on this draft and literature review and, as a result of the views from the experts in the field, a survey form was prepared including 26 
items to elicit parents' views regarding their children entrepreneurship skill gain. A pre-test was carried out with 41 parents who were chosen on a voluntary basis. According to the analyses, the Cronbach Alpha coefficient was calculated as 0.91 .

Entrepreneurship skills are supposed to be developed starting from the primary education in Turkey through life science courses at $1^{\text {st }}, 2^{\text {nd }}$ and $3^{\text {rd }}$ grades. The achievement in the course, parents" financial status and the child's gender and their self-confidence were included as independent variables. The gender was especially included as Turkey ranked 130 out of 144 countries in gender equality according to 2016 World Economic Forum data (http://www.dw.com/tr/t\%C3\%BCrkiyenin-cinsiyet-e\%C5\%9Fitli\%C4\%9Fi-karnesi/a-36162442).

\subsection{Data Collection and Analysis}

The data in this study was collected from 70 parents of the $3^{\text {rd }}$ grade students in the province of Adiyaman. The parents were asked to rate the 26 items in the Section II of the entrepreneurship skill gains survey form, with the responses "yes, always (5)", yes, often (4)", "yes, sometimes (3)", "yes, rarely (2)" and "no, never (1)" according to their observations regarding their children's/students' entrepreneurship skills. The maximum score that a student can get regarding their entrepreneurship skill gain is 130, which is obtained by reversing one of the items.

The entrepreneurship skill level was evaluated thusly; 1-33 points "bad", 34-66 "average", 67-99 points "good" and 100-130 points "very good".

Table 3. The entrepreneurship skill score of the 3rd grade students

\begin{tabular}{llllll}
\hline & $\mathrm{n}$ & Min. & Max. & $\mathrm{x}$ & $\mathrm{sd}$ \\
\hline Entrepreneurship Skill Score & 70 & 53 & 127 & 98.81 & 14.561 \\
\hline
\end{tabular}

As seen on Table 3, the minimum entrepreneurship skill level of the children/students according to their parents is 53 , whereas the maximum is 127 . The mean of the entrepreneurship skill level of the children/students is 98.81 , which corresponds to the level "good".

The independent samples t-test was used to compare the entrepreneurship skill level of the children/students following their entrepreneurship gains, as observed by their parents, with the parent's gender and the student's gender as independent variables. In order to test if the entrepreneurship skill level of the children/students changed according to the variables such as the students' success in school, the students' success in the Life Sciences course, their financial situation, and the students' self-confidence; one-way analysis of variance (ANOVA) was used.

\section{Findings}

This section includes the data regarding variables such as the children's/students' success in school and in the Life Sciences course, financial situation of the parents and the children's/students' self-confidence level, and how these variables affect the gains (scores) of the $1^{\text {st }}$ grade students in the Life Sciences course at the school, as evaluated by their parents;

Table 4 includes the variables such as the $3^{\text {rd }}$ grade primary school children's/students' success in school and in the Life Sciences course, financial situation of the parents and the students' self-confidence level according to their parents' observations.

Table 4. The frequency and the percentage distribution of the children's/students' success in school and in the Life Sciences course, financial situation of the parents and the children's/students' self-confidence level according to their parents' observations

\begin{tabular}{|c|c|c|c|c|c|c|c|c|}
\hline & \multicolumn{2}{|c|}{$\begin{array}{l}\text { The Students' Success } \\
\text { in School }\end{array}$} & \multicolumn{2}{|c|}{$\begin{array}{c}\text { The Students' Success in the } \\
\text { Life Sciences Course }\end{array}$} & \multicolumn{2}{|c|}{$\begin{array}{c}\text { The Financial Situation } \\
\text { of the Parents }\end{array}$} & \multicolumn{2}{|c|}{$\begin{array}{l}\text { The Students' Self-confidence } \\
\text { according to their Parents }\end{array}$} \\
\hline & $\mathrm{f}$ & $\%$ & $\mathrm{f}$ & $\%$ & $\mathrm{f}$ & $\%$ & $\mathrm{f}$ & $\%$ \\
\hline $\mathrm{Bad}$ & & & & & 5 & 7.1 & & \\
\hline Average & 4 & 5.7 & 5 & 7.1 & 32 & 45.7 & 8 & 11.4 \\
\hline Good & 28 & 40.0 & 27 & 38.6 & 33 & 47.1 & 36 & 51.4 \\
\hline $\begin{array}{l}\text { Very } \\
\text { Good }\end{array}$ & 38 & 54.3 & 38 & 54.3 & & & 26 & 37.1 \\
\hline Total & 70 & 100.0 & 70 & 100.0 & 70 & 100.0 & 70 & 100.0 \\
\hline
\end{tabular}

As it can be seen on Table 4, the parents expressed their children's/students' success in school as $54.3 \%$ "very 
good" ( $\mathrm{f}=38), 40 \%$ "good" ( $\mathrm{f}=28)$ and 5.7\% $(\mathrm{f}=4)$ "average"; their children's/students' success in the Life Sciences course as 54.3\% "very good" ( $\mathrm{f}=38), 38.6 \%$ "good" $(\mathrm{f}=27)$ and $7.1 \%(\mathrm{f}=5)$ "average"; their financial situation as $47.1 \%$ "good" ( $\mathrm{f}=33), 45.7 \%$ "average" $(\mathrm{f}=32)$ and $7.1 \% \quad(\mathrm{f}=6)$ "bad"; and their children's/students" self-confidence level as 51.4\% "good" ( $\mathrm{f}=36), 37.1 \%$ "very good" ( $\mathrm{f}=26)$ and $11.4 \%(\mathrm{f}=4)$ "average", respectively.

Table 5. The results of the t-test which was carried out to determine if the entrepreneurship skill level of the children/students displays a significant change depending on the variables such as parent's gender, the student's gender or the school type

\begin{tabular}{|c|c|c|c|c|c|c|c|c|}
\hline & & \multirow{2}{*}{$n$} & \multirow{2}{*}{$\mathrm{X}$} & \multirow{2}{*}{ ss } & \multirow{2}{*}{ Sh } & \multicolumn{3}{|c|}{$t$-Test } \\
\hline & & & & & & $t$ & $S d$ & $p$ \\
\hline \multirow{2}{*}{ Parent } & Mother & 47 & 100.83 & 11.541 & 1.683 & \multirow{2}{*}{1.677} & \multirow{2}{*}{68} & \multirow{2}{*}{0.016} \\
\hline & Father & 23 & 94.70 & 18.975 & 3.957 & & & \\
\hline \multirow{2}{*}{ Child/Student } & Female & 32 & 101.44 & 15.132 & 2.675 & \multirow{2}{*}{1.393} & \multirow{2}{*}{68} & \multirow{2}{*}{0.509} \\
\hline & Male & 38 & 96.61 & 13.877 & 2.251 & & & \\
\hline \multirow{2}{*}{ School Type } & Central & 30 & 99.13 & 14.829 & 2.707 & \multirow{2}{*}{0.158} & \multirow{2}{*}{68} & \multirow{2}{*}{0.886} \\
\hline & Disadvantaged Neighborhood & 40 & 98.58 & 14.541 & 2.299 & & & \\
\hline
\end{tabular}

As it can be seen on Table 5; as a result of the independent samples t-test which was carried out in order to determine if the entrepreneurship skill level of the children/students according to their parents displays a significant change depending on the parent's gender, a significant difference was detected between the means of the groups $(\mathrm{t}=1.677 ; \mathrm{p}<05)$. This difference is in favor of the mothers.

As a result of the independent samples t-test which was carried out in order to determine if the entrepreneurship skill level of the children/students according to their parents displays a significant change depending on the student's gender, there were not any statistically significant differences detected between the means of the groups $(\mathrm{t}=1.393 ; \mathrm{p}>.05)$.

As a result of the independent samples t-test which was carried out in order to determine if the entrepreneurship skill level of the children/students according to their parents displays a significant change depending on the school type, there were not any statistically significant differences detected between the means of the groups $(t=0.158$; $\mathrm{p}>.05)$.

Table 6. The results of the one-way variance analysis (ANOVA) which was carried out in order to determine if the entrepreneurship skill level of the children/students displays a significant change depending on the students' success in school

\begin{tabular}{lccccccccc}
\hline Group & $n$ & $X$ & $s s$ & Var. & $K T$ & $S d$ & $K O$ & $F$ & $p$ \\
\hline Average & 4 & 81.00 & 13.928 & Between Group & 1466.584 & 2 & 733.292 & & \\
Good & 28 & 98.32 & 13.092 & Within Group & 13162.002 & 67 & 196.448 & 3.733 & 0.029 \\
Very Good & 38 & 101.05 & 14.660 & Total & 14628.586 & 69 & & & \\
Total & 70 & 98.81 & 14.561 & & & & & & \\
\hline
\end{tabular}

$\mathrm{LF}=.126 ; \mathrm{p}>0.05$.

It can be seen on Table 6 that as a result of the one-way variance analysis (ANOVA) which was carried out in order to determine if the entrepreneurship skill level of the children/students displays a significant change depending on the children's/students' success in school, a significant difference was detected $(\mathrm{F}=3.733 ; \mathrm{p}<0.05)$. In order to see which groups were the sources of this significant difference, complementary post-hoc analyses were carried out. With the Levene's test, it was detected that the variance of the group distribution was homogenous $(\mathrm{LF}=0.126$; $\mathrm{p}>0.05$ ). Therefore, the LSD multiple comparison technique was chosen, which is commonly used when there is homogeneity of variance. The results of the LSD multiple comparison analysis are presented below. 
Table 7. The results of the post-Hoc LSD test following the one-way variance analysis (ANOVA) which was carried out in order to determine in which subgroups the entrepreneurship skill level of the students displays a change depending on the students' success in school

\begin{tabular}{lccccc}
\hline \multirow{2}{*}{ (I) Success } & (J) Success & Avr. Dif. & \multirow{2}{*}{ Sh } & $p$ & LSD \\
\cline { 3 - 5 } Average & Good & $-17.321^{*}$ & 7.492 & .024 & \\
& Very Good & $-20.053^{*}$ & 7.368 & .008 & \\
\multirow{2}{*}{ Good } & Average & $17.321^{*}$ & 7.492 & .024 & Very Good *-Average \\
& Very Good & -2.731 & 3.491 & .437 & Good*-Average \\
\multirow{2}{*}{ Very Good } & Average & $20.053^{*}$ & 7.368 & .008 & \\
& Good & 2.731 & 3.491 & .437 & \\
\hline
\end{tabular}

It can be seen on Table 7 that as a result of the post-hoc LSD test following the one-way variance analysis (ANOVA) which was carried out in order to determine in which subgroups the entrepreneurship skill level of the children/students displays a change depending on the children's/students' success in school; there was a statistically significant difference detected between the group "very good" and the group "average" in favor of the group "very good", and there was a statistically significant difference detected between the group "good" and the group "average" in favor of the group "good" $(p<0.05)$. According to these results, the entrepreneurship skill level of the students with a success level of "very good" and "good" in school were higher than the students with a success level of "average". In other words, there's a positive correlation between the entrepreneurship skill level of the children/students and their success in school.

Table 8. The results of the one-way variance analysis (ANOVA) which was carried out in order to determine if the entrepreneurship skill level of the students displays a significant change depending on the students' success in the Life Sciences course

\begin{tabular}{lccccccccc}
\hline Group & $n$ & $X$ & $s s$ & Var.C. & $K T$ & $S d$ & $K O$ & $F$ & $p$ \\
\hline Average & 5 & 89.00 & 12.981 & Between Group & 1628.691 & 2 & 814.345 & & \\
Good & 27 & 94.67 & 14.414 & Within Group & 12999.895 & 67 & 194.028 & & \\
Very Good & 38 & 103.05 & 13.680 & Total & 14628.586 & 69 & & & 0.019 \\
Total & 70 & 98.81 & 14.561 & & & & & & \\
\hline
\end{tabular}

$\mathrm{LF}=.209 ; \mathrm{p}>0.05$.

It can be seen on Table 8 that as a result of the one-way variance analysis (ANOVA) which was carried out in order to determine if the entrepreneurship skill level of the children/students according to the parents displays a significant change depending on the children's/students' success in the Life Sciences course, a significant difference was detected $(\mathrm{F}=4.197 ; \mathrm{p}<0.05)$. In order to see which groups were the sources of this significant difference, complementary post-hoc analyses were carried out. With the Levene's test, it was detected that the variance of the group distribution was homogenous ( $\mathrm{LF}=0.209 ; \mathrm{p}>0.05$ ). Therefore, the LSD multiple comparison technique was chosen, which is commonly used when there is homogeneity of variance. The results of the LSD multiple comparison analysis is presented below.

Table 9. The results of the post-Hoc LSD test following the one-way variance analysis (ANOVA) which was carried out in order to determine in which subgroups the entrepreneurship skill level of the students displays a change depending on the students' success in the Life Sciences course

\begin{tabular}{lccccc}
\hline \multirow{2}{*}{ (I) Success } & (J) Success & Avr. Dif. & \multirow{2}{*}{ Sh } & $p$ & LSD \\
\cline { 3 - 5 } Average & Good & -5.667 & 6.782 & .406 & \\
& Very Good & $-14.053^{*}$ & 6.627 & .038 & \\
\multirow{2}{*}{ Good } & Average & 5.667 & 6.782 & .406 & Very Good*-Average \\
& Very Good & $-8.386^{*}$ & 3.506 & .020 & Very Good*-Good \\
\multirow{2}{*}{ Very Good } & Average & $14.053^{*}$ & 6.627 & .038 & \\
& Good & $8.386^{*}$ & 3.506 & .020 & \\
& & & & & \\
\hline
\end{tabular}


It can be seen on Table 9 that as a result of the post-hoc LSD test following the one-way variance analysis (ANOVA) which was carried out in order to determine in which subgroups the entrepreneurship skill level of the children/students displays a change depending on the students' success in the Life Sciences course; there was a statistically significant difference detected between the group "very good" and the group "average" in favor of the group "very good", and there was a statistically significant difference detected between the group "very good" and the group "good" in favor of the group "very good" $(p<0.05)$. According to these results, the entrepreneurship skill level of the students with a success level of "very good" in the Life Sciences course were higher than the students with a success level of "good" and "average". In other words, there's a positive correlation between the entrepreneurship skill level of the students and their success in the Life Sciences course.

Table 10. The results of the one-way variance analysis (ANOVA) which was carried out in order to determine if the entrepreneurship skill level of the students displays a significant change depending on the parents' financial situation

\begin{tabular}{lccccccccc}
\hline Group & $n$ & $X$ & $s s$ & Var. C. & $K T$ & $S d$ & $K O$ & $F$ & $p$ \\
\hline Bad & 5 & 97.00 & 14.509 & Between Group & 108.852 & 2 & 54.426 & & \\
Average & 32 & 100.16 & 14.161 & Within Group & 14519.734 & 67 & 216.712 & & \\
Good & 33 & 97.79 & 15.270 & Total & 14628.586 & 69 & & & 0.251 \\
Total & 70 & 98.81 & 14.561 & & & & & & \\
\hline
\end{tabular}

It can be seen on Table 10 that as a result of the one-way variance analysis (ANOVA) which was carried out in order to determine if the entrepreneurship skill level of the children/students displays a significant change depending on the financial situation of the parents, there was not any significant difference $(F=0.251 ; p>0.05)$.

Table 11. The results of the one-way variance analysis (ANOVA) which was carried out in order to determine if the entrepreneurship skill level of the students displays a significant change depending on the students' self-confidence

\begin{tabular}{lccccccccc}
\hline Group & $n$ & $X$ & $s s$ & Var. C. & $K T$ & $S d$ & $K O$ & $F$ & $p$ \\
\hline Average & 8 & 87.00 & 10.212 & Between Group & 1764.297 & 2 & 882.149 & & \\
Good & 36 & 97.92 & 12.627 & Within Group & 12864.288 & 67 & 192.004 & & \\
Very Good & 26 & 103.69 & 16.191 & Total & 14628.586 & 69 & & & 0.013 \\
Total & 70 & 98.81 & 14.561 & & & & & & \\
\hline
\end{tabular}

$\mathrm{LF}=1.161 ; \mathrm{p}>0.05$.

It can be seen on Table 11 that as a result of the one-way variance analysis (ANOVA) which was carried out in order to determine if the entrepreneurship skill level of the children/students displays a significant change depending on the children's/students' self-confidence, a significant difference was detected $(\mathrm{F}=4.594 ; \mathrm{p}<0.05)$. In order to see which groups were the sources of this significant difference, complementary post-hoc analyses were carried out. With the Levene's test, it was detected that the variance of the group distribution was homogenous $(\mathrm{LF}=1.161 ; \mathrm{p}>0.05)$. Therefore, the LSD multiple comparison technique was chosen, which is commonly used when there is homogeneity of variance. The results of the LSD multiple comparison analysis is presented below.

Table 12. The results of the post-Hoc LSD test following the one-way variance analysis (ANOVA) which was carried out in order to determine in which subgroups the entrepreneurship skill level of the students displays a change depending on the students' self-confidence

\begin{tabular}{|c|c|c|c|c|c|}
\hline (I) Success & (J) Success & $\frac{\text { Avr. Dif. }}{(I-J)}$ & $S h$ & $p$ & $L S D$ \\
\hline \multirow{2}{*}{ Average } & Good & $-10.917^{*}$ & 5.416 & .048 & \\
\hline & Very Good & $-16.692^{*}$ & 5.602 & .004 & \\
\hline \multirow{2}{*}{ Good } & Average & $10.917^{*}$ & 5.416 & .048 & Very Good*-Average \\
\hline & Very Good & -5.776 & 3.566 & .110 & Good*-Average \\
\hline \multirow{2}{*}{ Very Good } & Average & $16.692^{*}$ & 5.602 & .004 & \\
\hline & Good & 5.776 & 3.566 & .110 & \\
\hline
\end{tabular}


It can be seen on Table 12 that as a result of the post-hoc LSD test following the one-way variance analysis (ANOVA) which was carried out in order to determine in which subgroups the entrepreneurship skill level of the children/students displays a change depending on the students' self-confidence; there was a statistically significant difference detected between the group "very good" and the group "average" in favor of the group "very good", and there was a statistically significant difference detected between the group "good" and the group "average" in favor of the group "good" $(p<0.05)$. According to these results, the entrepreneurship skill level of the students with a self-confidence level of "very good" and "good" were higher than the students with a self-confidence level of "average". In other words, there's a positive correlation between the entrepreneurship skill level of the children/students and their self-confidence.

\section{Results, Discussion and Suggestions}

This study is carried out in order to determine the entrepreneurship skill gains of the $3^{\text {rd }}$ grade students according to the observations of their parents. $42.9 \%$ of the students in our study group attend primary schools in a central location, whereas $57.1 \%$ of them attend primary schools in disadvantaged neighborhoods. $67.1 \%$ of the 70 parents in this study were mothers, whereas $32.9 \%$ of them were fathers. $45.7 \%$ of the children/students were female, whereas $54.3 \%$ of them were male (Table 2 ).

The entrepreneurship skill level of the $3^{\text {rd }}$ grade students was 98.81 out of 130 according to the observations of the parents, which is "good" (Table 3). The entrepreneurship skill level of the children/students showed a significant difference depending on the parent variable (mother or father), in favor of the mothers. The children's entrepreneurship skill gains level was higher according to the mothers in comparison to the fathers (Table 5). Mahler (1968) believes that at the beginning of an individual's personality development, they are psychologically integrated with their mothers; whereas they separate from them incrementally over the course of their life (Akt. Corey, 2008:90). This finding may be resulting from the mothers' extensive knowledge about their children since they are more involved with the daily life and the school life of their children than the fathers. According to the previous study regarding school life; it was seen that the mothers were more involved with the school life of the children (İpek, 2011; Özbaş, 2009; Aslanargun, 2007; Arslan, 2006), and that the teachers were holding the mothers accountable regarding the children's education (Özgan \& Aydın, 2010).

The entrepreneurship skill level of the children/students according to their parents did not display a significant difference depending on the students' gender (Table 5). This may be interpreted as the gender inequality reported at 2016 World Economic Forum is not affected from the female students' entrepreneurship qualities.

The parents of the $3^{\text {rd }}$ grade students rated their children's success in school as "very good" (54.3\%), "good" (40\%) and "average" (5.7\%) respectively. They rated their children's success in the Life Sciences course as "very good" (54.3\%), "good" (38.6\%) and "average" (7.1\%). According to the parents, the students" success in school and their success in the Life Sciences course were similar. There was a significant difference $(p<0.05)$ detected in the students' entrepreneurship skill level depending on their success in school. This difference was in favor of the group "very good" between the group "very good" and the group "average", and in favor of the group "good" between the group "good" and the group "average" (Table 6, Table 7). There was also a significant difference $(p<0.05)$ detected in the students' entrepreneurship skill level depending on their success in the Life Sciences course. This difference was in favor of the group "very good" between the group "very good" and the group "average", and in favor of the group "very good" between the group "very good" and the group "good" (Table 8, Table 9).

According to the findings of our study, there is positive correlation between the entrepreneurship skill level of the $3^{\text {rd }}$ grade students and their success in school and the Life Sciences course (Table 6, Table 7, Table 8, and Table 9). There is a correlation between the children's classroom experience, and their self-confidence levels and development of personality (Ültanır, 2003, p. 126). Every kind of success provides motivation and self-confidence for the child to overcome the next problem they face (Daniels and Peters, 2015:165). As a matter of fact, some students can only improve their self-confidence through academic success (Ültanır, 2003, p. 260).

The parents defined their financial situation as "good" (47.1\%), "average" (45.7\%) and "bad" (7.1\%) respectively. The entrepreneurship level of the $3^{\text {rd }}$ grade students did not change significantly according to the financial situation of the parents (Table 10).

The parents defined the self-confidence of their children as "good" (51.4\%), "very good" (37.1\%) and "average" $(11.4 \%)$, respectively (Table 4$)$. The entrepreneurship level of the $3^{\text {rd }}$ grade students varied significantly according to their self-confidence $(\mathrm{p}<0.05)$. When the groups were compared, it was detected that this difference was in favor of the "very good" group over the "average" group and also in favor of the "good" group over the "average" group regarding self-confidence. So, the entrepreneurship skill level of the students who had "very good" or "good" 
self-confidence levels were higher than the ones with "average" self-confidence. In other words, there is a positive correlation between high self-confidence and the entrepreneurship skill level of the children/students (Table 11, Table 12). Previous studies show that there is also a positive correlation between self-confidence and the cognitive, social, affective and psychomotor skills of children (Özdemir, 2016; Kolucka \& Lemish, 2011; Güneş, 2017; Yarımkaya, 2013; Bulut \& Kılıçaslan, 2009; Andreasen, 2005; Schunk, 2009; Tokinan \& Bilen, 2011; Karagül, 2012; Akkaya, 2012).

Since self-confidence has various aspects, it is difficult to define an individual as a person with high or low self-confidence (Aky1ldiz, 2010:937). Self-confidence is defined as an individual's positive self-appraisal, feeling of satisfaction about who they are as a person, ability to trust their own skills in the face of problems, to recognize their emotions and skills, and to trust in themselves (Çardak, 2012; Çelik, 2012; Özbey, 2004; Bandura, 1997). There is a two-way relationship between entrepreneurship and self-confidence. As entrepreneurship training contributes to building self-confidence, being a person with high self-confidence may have a positive impact on entrepreneurship (Uluköy, Demireli, \& Kahya, 2013).

The entrepreneurship skill level of the students did not show significant differences according to their gender, the type of their school or the financial situation of their parents. There is a positive correlation between the entrepreneurship skill level of the students and their success in the school and the Life Sciences course. The students who are successful in the school and the Life Sciences course also scored higher in their entrepreneurship skill level.

Another finding of this study is that the students with high self-confidence were scored higher in their entrepreneurship skill level.

Taking into consideration the positive correlation between the entrepreneurship skills and the students' self-confidence, their success in the school and the Life Sciences course; it is seen that in the competitive society of our day, we need to focus on building the children's self-confidence for them to survive (Ültanır, 2003, p. 254). Considering that warm, safe and supportive environments help the children build self-confidence (Çardak, 2012, p. 3); the teachers need to work on increasing the children's self-respect and self-confidence in any kind of learning environment (Ültanır, 2003, p. 23), and they should not allow the impressionable children's self-confidence to be shaken by classifying them as smart and not smart (Robinson, 2003:99).

In accordance with the results of this study, it can be suggested that;

The teachers carry out activities that will make the students feel successful in cognitive, social and affective areas in the learning environment, since there's a positive correlation between the students' self-confidence and their success in school, Life Sciences course, and entrepreneurship;

The parents carry out activities at home that will help the primary school students gain self-confidence and the fathers become involved in their children's school life as much as their mothers are;

Studies with large sample sizes are carried out that will show the impact of other primary school courses on the entrepreneurship skills of the children in addition to the Life Sciences courses;

Projects are carried out in primary schools that will build self-confidence and guide the teachers and the parents, since there is a positive correlation between self-confidence and the entrepreneurship skills of the students.

\section{References}

Akınoğlu, O. (2005). Hayat Bilgisi ve Hayat Bilgisi Öğretimi, Hayat bilgisi ve sosyal bilgiler öğretimi. Edt. Cemil Öztürk ve Dursun Dilek, 5. Baskı, Ankara: Pegem A yayınc1lık.

Akkaya, A. (2012). Öğretmen adaylarının konuşma sorunlarına ilişkin görüşleri, Mustafa Kemal Üniversitesi Sosyal Bilimler Enstitüsü Dergisi, 9(20), 405-420.

Akyıldız, M. (2010). Özgüven duygusu marka bağlılığını gerçekten artırır mı? Ege Akademik Baklş, 10(3), 933-950.

Andreasen, N. (2005). Yaratıcı beyin dehanın nörobilimi. Cev. Kıvanç Güney, Ankara: Akılçelen Kitaplar

Arseven, A. (2001). Alan araştırma yöntemi. Ankara: Gündüz Eğitim ve Yayıncılık.

Arslan B. (2006). Ailenin sosyo-demografik özelliklerinin çocuğun okuldaki sosyal etkinliklere katılımına etkisi (Türkiye ve Hollanda'daki ilköğretim 5. sinıf ögrrencileri üzerinde karşılaştırmalı bir çalışma). Yayımlanmamış Yüksek Lisans Tezi, İzmir: Ege Üniversitesi Sosyal Bilimler Enstitüsü.

Aslanargun, E. (2007). Okul-aile işbirliği ve öğrenci başarısı üzerine bir tarama çalışması, Manas Üniversitesi 
Sosyal Bilimler Dergisi, 18, 119-135.

Ay, S. T., \& Acar, Ş. (2016). Sınıf öğretmenlerinin girişimcilik becerisi kazandırmaya yönelik görüşleri, Elektronik Sosyal Bilimler Dergisi, 15(58), 960-976.

Bandura, A. (1997). Self-Efficacy: The Exercise of Control. New York: Freeman an Company.

Bozkurt, Ö., \& Erdurur, K. (2013). Girişimci kişilik özelliklerinin girişimcilik eğilimindeki etkisi: Potansiyel girişimciler üzerinde bir araştırma, Girişimcilik ve Kalkınma Dergisi, 8(2), 57-78.

Bulut, Z., \& Kılıçaslan, Ç. (2009). Çocuğa özgüven kazandırmada önemli bir ilke; çocuk oyun alanlarında güvenlik. Artvin Çoruh Üniversitesi Orman Fakültesi Dergisi, 10(1), 78-75

Büyüköztürk, Ş., Çakmak, E., Akgün, Ö., Karadeniz, Ş., \& Demirel, F. (2008). Bilimsel araştırma yöntemleri, 1. Baskı, Ankara: Pegem Akademi Yayınları.

Çardak, M. (2012). Gelişim psikolojisi, Psikoloji ve eğitimde kullanılan güncel ölçme araçları. Edt. Ahmet Akın, Ankara: Nobel Yayınları.

Çelik, A., İnce, M., \& Bozyiğit, S. (2014). Üniversite öğrencilerinin girişimcilik niyetlerini etkileyen ailesel faktörleri belirlemeye yönelik bir çalışma. Niğde Üniversitesi İktisadi ve İdari Bilimler Fakültesi Dergisi, 7(3), 113-124.

Çelik, E. (2012). Cinsellik, Psikoloji ve eğitimde kullanılan güncel ölçme araçları. Edt. Ahmet Akın, Ankara: Nobel Yayınları.

Çermik, F., \& Şahin, İ. (2015). Sosyal bilgiler öğretmeni adaylarının sosyal girişimcilik özelliklerinin çeşitli değişkenler açısından incelenmesi. Current Research in Education, 1(2), 76-88.

Corey, G. (2008). Psikolojik Danışma Kuram ve Uygulamaları. Cev. Tuncay Ergene, Ankara: Mentis yayıncılık.

Daniels, S., \& Peters, D. (2015). Yaratıcı çocuklar yetiştirmek. Cev. Edt. Üzeyir Oğurşu ve Fatih Kaya, Ankara: Eğiten Kitap.

Duval-Couetil, N. (2013). Assessing the Impact of Entrepreneurship Education Programs: Challenges and Approaches. Journal of Small Business Management, 51(3), 394-409. https://doi.org/10.1111/jsbm.12024

Eraslan, L. (2011). İlköğretim Programlarında Girişimcilik Öğretimi (Hayat bilgisi dersi örneği). Gazi Üniversitesi Endüstriyel Sanatlar Eğitim Fakültesi Dergisi, 27, 82-94.

Güneş, A. (2017). Eğitimde yaratıcılık ve yaratıcı mekânlar. Eğitim Bilim ve Toplum Dergisi, 15(57), 37-56.

Güven, S. (2010). Hayat bilgisi dersi öğretim programlarının girişimcilik özellikleri açısından incelenmesi. e-Journal of New World Sciences Academy, 5(1), 49-57.

İpek, C. (2011). Velilerin okul tutum ve eğitime katılım düzeyleri ile aileye bağlı bazı faktörlerin ilköğretim öğrencilerinin seviye belirleme sınavı (SBS) üzerindeki etkisi. Pegem Ĕgitim ve Öğretim Dergisi, l(2), 69-79. https://doi.org/10.14527/C1S2M7

Kabapınar, Y. (2009). İlköğretimde hayat bilgisi ve sosyal bilgiler eğitimi. 2. Bask1, Ankara: Maya Akademi

Karagül, S. (2012). Özerk benlik gelişimi ve yabancı dilde eğitim. Çă̆daş Türk Dili, 288,725-733.

Karasar, N. (1998). Bilimsel araştırma yöntemi. 8. Basım, Ankara: Nobel Yayınları.

Kolucki, B., \& Lemish, D. (2011). Çocuklarla iletişim.

Kuratko, D. F. (2005). The Emergence of Entrepreneurship Education: Development, Trends, and Challenges. Entrepreneurship Theory and Practice, 29(5), 577-598. https://doi.org/10.1111/j.1540-6520.2005.00099.x

M.E.B. (2017). Hayat bilgisi ögretim programı. Ankara.

Özbaş, M. (2009). İlköğretim okulu yöneticilerinin okul-aile ilişkileri konusunda yapmaları gereken ve yapmakta olduklart işler. Yayımlanmamış Doktora Tezi, Ankara: Hacettepe Üniversitesi Sosyal Bilimler Enstitüsü.

Özbey, Ç. (2004). Çocuk sorunlarına yapıcı çözümler. İstanbul: İnkılap Kitapevi

Özdemir, N. (2016). Deneysel Bir Çalışma: Bibliyopsikolojik Danışmaya Dayalı Özgüven Geliştirme Programının 6. Sınıf Öğrencilerinin Özgüven düzeylerine Etkisi. Illkögretim Online, 15(1), 136-147. https://doi.org/10.17051/io.2016.59570

Özgan, H., \& Aydın, Z. (2010). Okul-aile işbirliğine ilişkin yönetici, öğretmen ve veli görüşleri. e-Journal of New World Sciences Academy, 5(3), 1169-1189. 
Pan, V., \& Akay, C. (2015). Eğitim fakültesi öğrencilerinin girişimcilik düzeylerinin çeşitli değişkenler açısından incelenmesi. e-Journal of New World Sciences Academy, 10(2), 125-138., https://doi.org/10.12739/NWSA.2015.10.2.1C0637

Polat, H., \& Ünişen, A. (2016). Ebeveyn görüşlerine göre hayat bilgisi eğitimini almış çocularının bilinçli tüketici olma durumları. Ë̌itimde Kuram ve Uygulama, 12(3), 670-694.

Robinson, K. (2003). Yaratıcılık aklın sınırlarını aşmak. Cev. Nihal Geyran Koldaş, İstanbul: Kitap Yayınevi

Şahin, M. (2009). Cumhuriyetin kuruluşundan günümüze Türkiye'de hayat bilgisi dersi programlarının gelişimi. Uluslararası Sosyal Araştırmalar Dergisi, 2(8), 401-410.

Schunk, D. (2009). Öğrenme teorileri-eğitimsel bir bakışla. Cev. Edt. Muzaffer Şahin, Ankara: Nobel Yayın Dağıtım

Van der Sijde, P., Ridder, A., Blaauw, G., \& Deinsberg, C. (Eds.). (2008). Teaching entrepreneurship: Cases for education and training. Phyca-Verlag. https://doi.org/10.1007/978-3-7908-2038-6

Sönmez, V. (2010). Hayat bilgisi öğretimi ve öğretmen kılavuzu. Yenilenmiş 6. Baskı, Ankara: Anı yayıncılık.

Tokinan, B., \& Bilen, S. (2011). Yaratıcı dans etkinliklerinin motivasyon, özgüven, özyeterlik ve dans performansı üzerindeki etkileri. Hacettepe Eğitim Fakültesi Dergisi (H:U: Journal of Education), 40, 363-374.

Ültanır, E. (2003). İlköğretim birinci kademede rehberlik ve danışma. Ankara: Nobel Yayın Dağıtım

Uluköy, M., Demirel, C., \& Kahya, V. (2013). KOSGEB girişimcilik eğitimi kurslarına katılan katılımcıların girişimcilik profiline yönelik bir alan araştırması. Girişimcilik ve Kalkınma Dergisi, 8(2), 79-96.

Ünişen, A. (2013). II. Meşrutiyet Döneminde İstanbul'da yayımlanan başlıca mecmualardaki eğitim bilimleriyle Ilgili makalelerin değerlendirilmesi (Yayımlanmamış Doktora Tezi). Gaziantep: Gaziantep Üniversitesi, Eğitim Bilimleri Enstitüsü.

World Economic Forum. (2016). Retrieved from http://www.dw.com/tr/t\%C3\%BCrkiyenin-cinsiyet-e\%C5\%9 Fitli\%C4\%9Fi-karnesi/a-36162442

Yarımkaya, E. (2013). 12-14 yaş arası ilköğretim öğrencilerinin özgüven düzeylerinin voleybolda servis atma becerisi üzerine etkileri. Yayınlanmamış yüksek lisans tezi. Konya: Selçuk Üniversitesi Sağlık Bilimleri Enstitüsü.

\section{Copyrights}

Copyright for this article is retained by the author(s), with first publication rights granted to the journal.

This is an open-access article distributed under the terms and conditions of the Creative Commons Attribution license (http://creativecommons.org/licenses/by/4.0/). 